DOI 10.18551/rjoas.2019-11.16

\title{
FOOD SECURITY AS A SPECIFIC ISSUE OF POLITICAL CAMPAIGNS DURING GOVERNOR ELECTION IN CENTRAL JAVA OF INDONESIA
}

\author{
Luqman Yanuar*, Lailiyah Nuriyatul, Yuliyanto Muchammad \\ Department of Communication, Faculty of Social and Political Sciences, \\ University of Diponegoro, Semarang, Indonesia \\ *E-mail: yanuar.luqman@live.undip.ac.id
}

\begin{abstract}
The election of the Governor of Central Java in 2018 result was Ganjar Pranowo and Taj Yasin as the winners. Messages in political campaigns are important elements that can determine the candidate's victory or failure in political contestation. The messages in the campaign are specifically designed based on the character of the specific target voters and should not be generalized to all groups of voters. As one of the national food barns, it was interesting to figure out how specific messages related to food security are perceived by voters. The research method used was a mixed method with in-depth interviews with voters with agricultural background and survey to young voters who are considered by researchers to have the greatest opportunity to be exposed by a variety of specific issues in the campaign because of their high media consumption. The results of the study show that specific issue like food security was only a concern for voters who have strong relevance to the issue. However, it was not the only basis for consideration in choosing candidates for related voters.
\end{abstract}

\section{KEY WORDS}

Campaign, election, food security, Indonesia, politics.

On 27 June 2018, the Central Java Province held a regional election synchronously in seven regions including the gubernatorial election (Pilgub). This activity of the five-year political event since middle February that has been determined by the General Election Commissions (KPU) that there were two candidates of governor pairs namely Ganjar Pranowo - Taj Yasin and Sudirman Said-Ida Fauziah, followed by campaign activities for more than four months. This campaign as an effort to introduce the vision and mission while "selling" the work program to voters is one form of political communication between candidates with the community as constituents in this electoral democracy. The campaign has become a mandatory agenda because of the inherent part of any political contestation such as the election of the governor - vice governor since it was held in 2005.

A research with the object of elections in Australia in 2013 showed that political party and politicians those who were ruling tend to make the policy that only helps to wide society, but also expected to increase voter support for them. That was an attempt to communicate the values and character of the political party and the leaders. There were even findings who showed that policy decision was encouraged by data and reflect the specific target group of voters. This research also showed that the general election then becomes a strategic way for the political party in using policies when having the power to facilitate their campaigns and defeat the opponent. (Reece, 2017).

In this campaign, the governor candidates delivered their various programs which were not from strategic issues for Central Java society, so that it was expected to gain appreciation and event electability support during the election. The fundamental problem that often becomes an issue in Central Java campaigns, one of them related to food security. Especially during this time, the Central Java Province has been known as one of the food barns as a buffer for the availability of national food needs since the New Order era. Besides, the data shows that the majority of the Central Java society (63,5\%: BPS;2017) live in rural areas based on economic life in the agricultural sector, and some people life in coastal 
fishing and salt ponds. Therefore, the issue of food security was one of the agenda delivered by the governor candidate as a promise as well as a real effort to improve people's welfare.

The messages in this political campaign are the important elements that can determine the candidate's victory or failure in political contestation. In Central Java Governor Election Campaign 2018 which was only followed by two pairs of candidates, ideally, each candidate offered a different kind of things that compared with competitors to gain sympathy and support from voters. These messages in the campaigns are specifically designed based on the character of the specific target voters and can't be generalized that one massage applies to all groups of voters. In the context of Central Java as one of the food barns in Indonesia, food security issues are important for the campaign material for voters. The voter group who live in agricultural areas is a group that has a close relationship with food policies that will be carried out by the Governor of Central Java.

Political candidates tend to highlight positive messages for themselves and negative messages for competitors. message in politics is as important as the brand in marketing (Silverstein, 2011) message in a political campaign could include promises or pledges. Research showed that citizens were more likely to perceive messages as pledges when they were general and not so specific. Such political messages are remembered by people as stronger than specific political messages (Dupont et al. 2019). Despite to that situation, research found that student respondents in united states and England of all ages expressed concerns about the trustworthiness of candidates and understood that the promises politicians make are not always kept (Rivers et al. 2018).

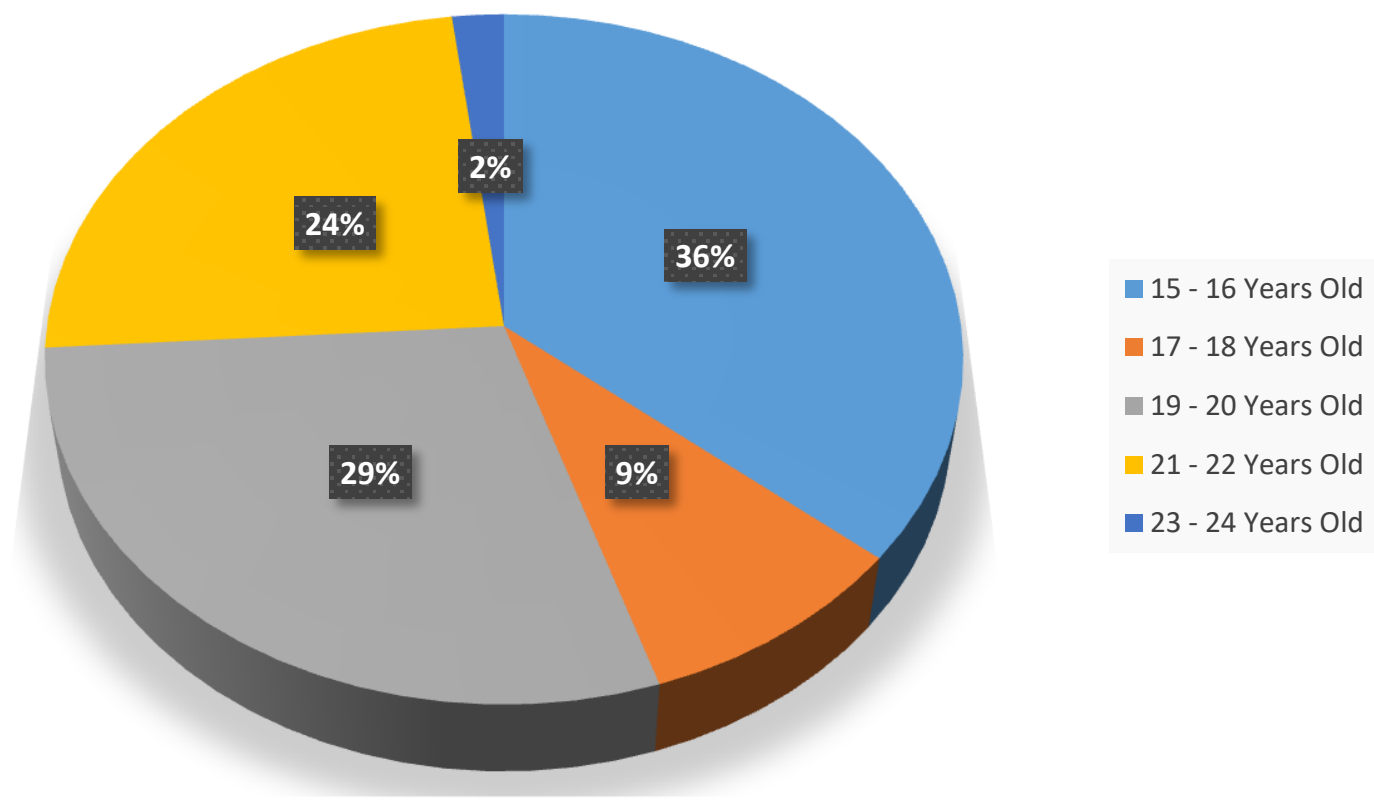

Figure 1 - Respondents Age's

This research used a mixture of quantitative and qualitative methods. In the quantitative method, the technique of data collection was through a survey of young voters among high school students and college students. The assumption is novice voters have access to campaign information for the Central Java Governor Election Campaign better than other voter groups. Their skills in using social media and the internet make them have more chances to be exposed the specific campaign issues than the other voter groups. The survey was conducted on 100 high school students and college students. This technique sampling is purposive with the criteria of novice voters, residents of Central Java and knowing there was a Central Java Governor election in 2018. In qualitative methods, the techniques of data collection were carried out by in-depth interviews with people who related 
to agriculture in various cities in Central Java such as Solo, Pekalongan, Magelang, Wonosobo, and Kebumen. Assuming this voter group has more potential to pay attention to these food security issues than the other voter groups.

The attachment of young voters to social media also provide them chances to participate more in politics, including to realize that there were specific messages that made the two competing candidates different from each other. Because in politics, social media tends to be more political (Yamamoto and Morey 2019). Even though the young generation tends to avoid political messages and information that spread on social media (Lailiyah, Yuliyanto, and Pradhana 2018).

\section{DISCUSSION OF RESULTS}

The result of the research showed that the voters had tended not to pay attention to the specific issues in this campaign unless the issue is related to themselves and their environment. In the novice voters group, only $1 \%$ have paid attention to food security issues in Central Java Governor Election 2018. Even though Ganjar Pranowo also stated that the issue related to food security, specifically the farm cards, became a material for his political opponents to be politicized. The policy that he designed as one of his superior programs to attack their opponents. He felt that his vote wasn't as big as the expectations of his team due to the success of the opponent to play of farm cards issue. One of the prominent programs often delivered by Sudirman Said and Ida Fauziyah as the opponent was to remove the farm card program which's felt not to be impartial for farmers and just make's difficult the farmers to access fertilizer and other assistance. The politicization of farm card issues in this Central Java Governor Election made the issue relatively have much highlighted by the media. But voters from the younger generation pay more attention to economic issues (as much as $39 \%)$ or instead pay attention to specific issues (26\%).

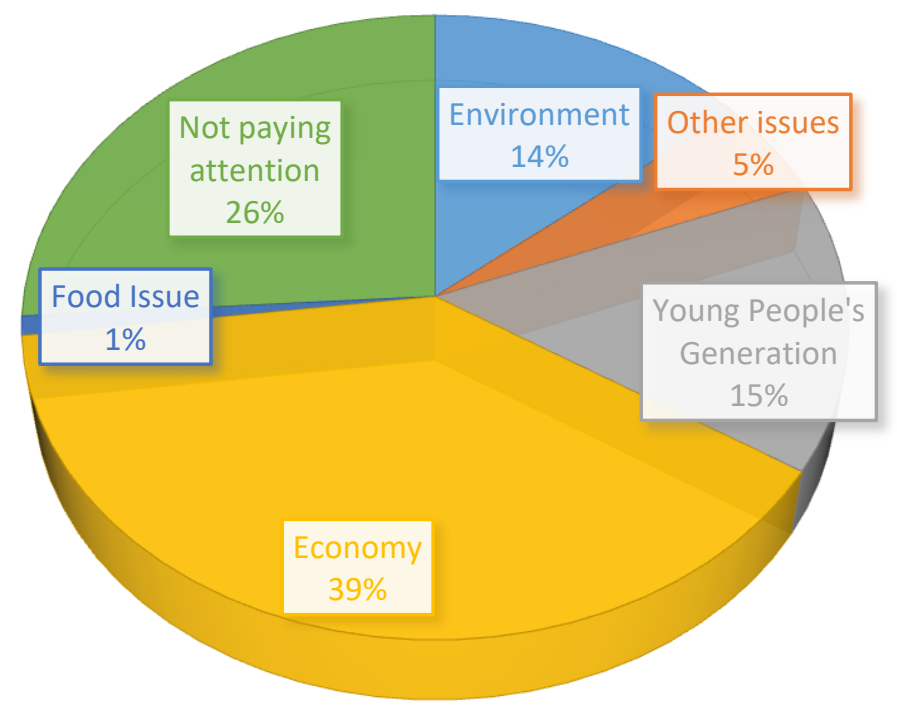

Figure 2 - The Most Noticed issues during the 2018 Central Java Governor Election Campaign

Specific issues also have been raised in the presidential election campaign in America, when Al Gore form Democrat Party against George Bush jr from the Republican party. Some of the specific issues that stand out and distinguish between the two candidates were about the environment. Al Gore felt that handling global warming must also be supported by the society apart from the government itself. While George Bush jr thought that the solution to global warming was mainly forming the government based on data and science (Campbell, 2018).

In a study related to donations that were given by voters in campaigns, it was found that voters who donated to more than one competing candidate tended to repeat their 
donations if there were negative messages related to other candidates (Niebler and Urban 2017). This shows that the message needs to have a negative and positive nature in the campaign to cause the behavior expected by the campaigners. Therefore, when the issue of the Farmer Card had been intended as a positive program by the incumbent candidate, it became a boomerang when the same message was used by his opponent to attack.

The policy of candidates who related to food security which voters consider is incumbent policies, among the others related to farm cards which have an impact on access to subsidized fertilizers and the other. The application of the farm cards program in reality by informants was seen as a shortcoming of Ganjar's leadership as Governor. Nevertheless, most of the informants in this study chose Ganjar as their chosen candidates. With the lack of farm cards owned by Ganjar, it doesn't make Ganjar considered less superior than the other candidates. The issue for the informants was the other candidates were more unknown, so it was not sufficient to be chosen in Central Java Governor Election 2018.

The informant in Magelang who also claimed to vote Ganjar, considered the farm card as Ganjar's policy was not quite popular among the farmers. According to her, the farm card can only be accessed by those people who have their land. Because of the requirement, to show the certificate of land ownership to get a farm card. For informants in Magelang, poor farmers can't access those requirements. Nevertheless, the informants in Magelang felt that they haven't had any choices except Ganjar. She felt that she didn't have enough time to process all campaign information properly, so she only felt to choose the candidates that she already knew, namely is Ganjar Pranowo as an incumbent. With all of his excess and deficiency while in office, for him Ganjar still is the best choice among the available choices.

When the researcher interviewed Ganjar as the one who was currently selected as Governor of Central Java, the researchers found a different fact. Ganjar as an incumbent who at this time had a farm card policy stated that the obligation to show land ownership certificates could also be carried out by farm workers. Farm workers could borrow the landowners' certificate to show it as proof that he is working on someone else's land. Ganjar acknowledged that farm cards implementation in reality still has many obstacles. According to him, the biggest obstacle is the unpreparedness of the infrastructure owned by Central Java Government to collect data as well as socialize the farm cards program. He gave an example that data collection officers often make data by estimating instead of collecting the real data. As a consequence, farmers' needs such as fertilizer and others cannot be optimally fulfilled due to poor data collection. For Ganjar, the right data is good capital for better policy management, especially concerning farm cards. Poor data causes poor program implementation. He also believed that the farm cards program which was basically good and ideally could be a solution to various problems for farmers was used by political opponents to attack the policies he had begun. According to Ganjar, the farm cards became one of the causes (Abou-Chadi 2018) that his number of voters' target was not as many as he had expected. Although he was the winner in Governor election.

A study shows that parties tend to be responsive to issues that become priority voters. When the party tries to hitch a wave of issues as a strategy, actually it depends on the preferences of the supporters and the voters as a whole. But in the competition that gets tighter and, other parties begin to give priority to the popular issues, some parties starts using risky strategies by prioritizing issues that are less important to their supporters. This problem was intended to make a difference in position compared to other existing parties at the same time. This gives an idea of why parties sometimes don't respond to popular issues. This researched also shows that although the party has a benefit when it becomes responsive to the needs of voters in general, the party's traditional supporters and brands. (Abou-Chadi, 2018). Like parties, politicians who are responsive to popular issues in society also have the same opportunities.

The result of in-depth interviews with informant voters who work as farmers showed answers that were not too much different between another informant. The farmer's informants stated that they didn't pay attention to candidate programs of the past Governor's election campaign. Both of them claimed to choose candidates because of the figure. They claimed to have Ganjar, despite they also acknowledging that Ganjar's Leadership as 
governor still had much deficiency. For them, it was better to choose what was certain. The Kebumen farmer's informants felt they didn't know the other candidates except for Ganjar. Even Taj Yasin as Ganjar partner they considered didn't know. When asked for the reason for choosing Ganjar, Kebumen informant chose Ganjar because of his program for the farmers.

For farmer informants in Wonosobo, the Governor election campaign 2018 was not important. For him, the most important thing was he can run his profession well. For him, the biggest obstacle faced when farming wasn't related to who the Centra Java Governor leading. The biggest problem he faced was that the weather was sometimes unfriendly for his farm. Farmer informants in Pekalongan during the Governor election 2018 claimed to have chosen Sudirman Said. He felt that Ganjar's policy, especially regarding the farm cards, was seen as not enough benefit for farmers.

"it's difficult for farmers, most farmers are small people. unusually associated with banks. He did it when he bought fertilizer right? if the small people were directly going to the farm stall, no intermediary was using an atm. How we want to save money if we don't have any passbook".

If the candidate doesn't have a benefit from the economic situation, make an issue that can be associated with the party or candidate and get it Bevan and Krewel 2015). Political campaigns are carried out to win elections and positions. A responsive campaign for the public will be able to encourage the public to give support for the campaign. (Bevan \& Krewel, 2015).

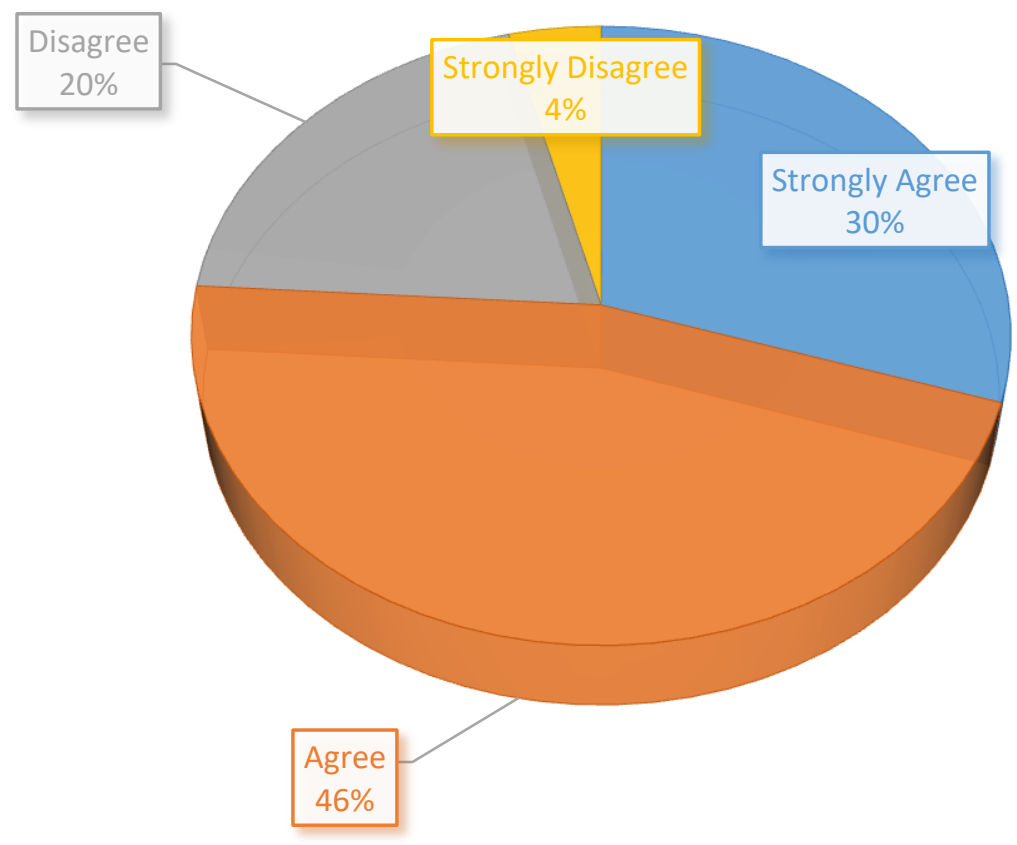

Figure 3 - Respondents Chose the Governor Based on Programs

Ganjar was aware that one of the programs that were expected to be positive turned out to be a program that reduced the potential number of votes that he might get. Ganjar sought to explain that the program in practice had deficiencies and could be improved. A study found that the consistency of messages in political campaigns is important to maintain the integrity of candidates (Bentley and Voges 2019).

If we analyzed using the elaboration likelihood model, we can see that the ability and motivation to process are the things that underline the processing of persuasive message in the lack of motivation in young voter respondents makes specific issues such as food security can't be processed by the central route. The food issue was one of many issues that have become a material of the Governor Centra Java election. However, this research can't conclude that respondents' motivations were weak against all of the issues or even related to 
the candidates. Especially if we see the result of the respondent's answer stating that the majority of them chose the Governor based on the program. The choice of preference base on the program shows that the central route signal is used in persuasion processing. The majority of respondents agreed that they choose the Governor because the program offered.

In another finding, the governor election was due to figuring consideration indicating that the peripheral route signal was used. The majority of respondents also agreed that they choose the governor because of figures.

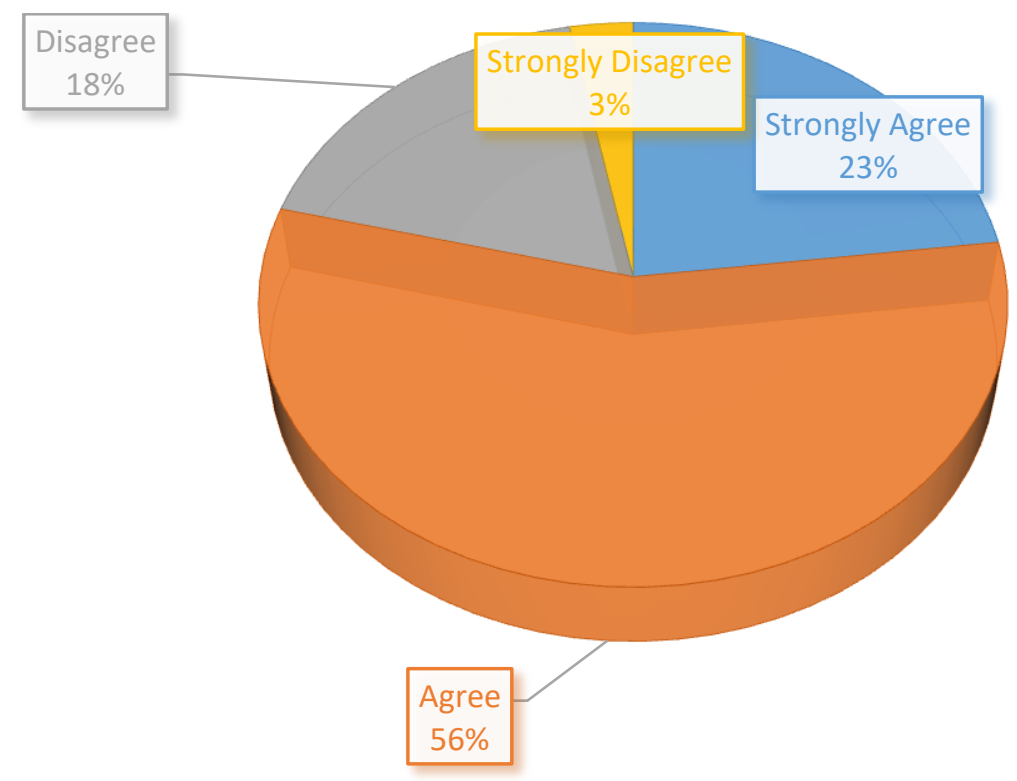

Figure 4 - Respondents chose the governor because of figures

From the findings above, it can be seen that young voter respondents choose Centra Java Governor because they saw their figures and programs. Choosing a governor candidate based on the program is a representation of uses of the middle route in processing persuasion messages. While selecting based on the figure shows uses of edge lane or peripheral in processing persuasion messages. Simultaneous uses of the middle lane or edge lane can occur in determining attitudes towards certain persuasive campaigns. Include in political campaigns. Using both paths at the same time can produce a strong and emotionally attached attitude.

\section{CONCLUSION}

Specific issues did not draw attention to voters who have no interest in these specific issues. In this study, the issue of food security as part of the issue that attracts the attention of voters from the agricultural sector, considering that the two pairs of candidates who compete in the Central Java Governor Election both of them make a farm card issue as a material for their campaign. Informants from the agricultural community felt that the farm cards as the program carried by Ganjar didn't show a good result for their lives. Interestingly, among the farmer informants who didn't like the farm cards program still choosing Ganjar, because they didn't know enough about the other candidates.

In voters who were assumed to have an opportunity to be exposed more information regarding the Central Java Governor Election was young voters, specific issues related to food security aren't a concern. In general, the younger generation voters said that the Governor's choice was decided because of their program offered and the figures of candidates. Viewed from the perspective of the Elaboration Likelihood Model, both of these indicate the existence of central signals as well as peripherals. Voters who decided on political choices by using peripheral and central pathways at the same time will emerge a strong and emotional attitude. 


\section{REFERENCES}

1. Abou-Chadi, Tarik. 2018. "Electoral Competition, Political Risks, and Parties' Responsiveness to Voters' Issue Priorities." Electoral Studies 55 (November 2017): 99108. https://doi.org/10.1016/j.electstud.2018.08.012.

2. Bentley, Joshua M., and Taylor Voges. 2019. "Representations of Reliability: The Rhetoric of Political Flip-Flopping." Public Relations Review 45(1): 1-9.

3. Bevan, Shaun, and Mona Krewel. 2015. "Responsive Elections: The Effect of Public Opinion on Political Campaigns." Electoral Studies 40: 548-55. http://dx.doi.org/10.1016/j.electstud.2015.07.006.

4. Dupont, Julia C, Evelyn Bytzek, Melanie C Steffens, and Frank M Schneider. 2019. "Which Kind of Political Campaign Messages Do People Perceive as Election Pledges ?" $\begin{array}{llll}\text { Electoral Studies } & 57 \quad \text { (November }\end{array}$ https://doi.org/10.1016/j.electstud.2018.11.005.

5. Lailiyah, Nuriyatul, Much Yuliyanto, and Ghozian Aulia Pradhana. 2018. "Youthizen , Political Literacy, and Social Media." In E3S Web of Conferences73, 14005 ICENIS 2018, EDP Sciences, 20-23. https://doi.org/10.1051/e3sconf/20187314005.

6. Niebler, Sarah, and Carly Urban. 2017. "Does Negative Advertising Affect Giving Behavior? Evidence from Campaign Contributions." Journal of Public Economics 146: 15-26. http://dx.doi.org/10.1016/j.jpubeco.2016.12.001.

7. Reece, Nicholas. 2017. "Making Policy and Winning Votes: Election Promises and Political Strategies in the 2013 Campaign." Abbott's Gambit: The 2013 Australian Federal Election.

8. Rivers, lan et al. 2018. "A Cross-National Study of School Students 'Perceptions of Political Messages in Two Election Campaigns." International Journal of Educational Research 92 (August): 10-19. https://doi.org/10.1016/j.ijer.2018.06.006.

9. Silverstein, Michael. 2011. "Language \& Communication The "'Message"' in the (Political) Battle." Language \& Communication 31: 203-16. www.elsevier.com/locate/langcom.

10. Yamamoto, Masahiro, and Alyssa C Morey. 2019. "Incidental News Exposure on Social Media : A Campaign Communication Mediation Approach." Social Media + Society (AprilJune): 1-12. 